\title{
MANAJEMEN LIKUIDITAS LEMBAGA KEUANGAN MIKRO SYARIAH NON BANK (BMT) DENGAN AKAD TAWARRUQ
}

\section{Edi Susilo}

Dosen Prodi Ekonomi Islam Fakultas Ekonomi dan Bisnis

Universitas Islam Nahdlatul Ulama - Jepara edisusilo@unisnu.ac.id

\begin{abstract}
Non-bank Islamic microfinance institutions (BMT) are legal entity Cooperative have no instrument to fulfill liquidity needs as Islamic banking. Whereas the BMT should provide liquidity fund for the partners / members at any time. This article uses descriptive analytical method, to understand deeply the Tawarruq contract as liquidity management solutions Non-bank Islamic Microfinance Institutions (BMT). The results show the Tawarruq contract can be revitalized by necessity of the present to fulfill the liquidity needs of Non-bank Islamic Microfinance Institutions $(B M T)$.
\end{abstract}

Keywords: Tawarruq, Islamic Microfinance Institutions, BMT

\begin{abstract}
ABSTRAK
Lembaga keuangan mikro syariah non bank (BMT) yang berbadan hukum Koperasi tidak memiliki instrument dalam memenuhi kebutuhan likuiditas hariannya sebagaimana perbankan syariah. Padalah BMT harus menyediakan dana likuiditas kepada mitra /anggotanya yang mengambil dananya sewaktu-waktu. Artikel ini menggunakan metode deskriptif analitis, untuk memahami secara mendalam akad tawarruq sebagai solusi manajemen likuiditas Lembaga Keuangan Mikro Syariah non bank (BMT). Hasil kajian menunjukkan Akad Tawarruq dapat dirivitalisasi berdasarkan kebutuhan masa kini untuk memenuhi kebutuhan likuiditas lembaga keuangan mikro non bank (BMT).
\end{abstract}

Kata Kunci : Tawarruq, Lembaga Keuangan Mikro Syariah, BMT 


\section{PENDAHULUAN}

Lembaga keuangan mikro syariah (LKMS) seperti BMT, sebagai entitas lembaga keuangan yang beroperasi selayaknya perbankan dengan menghimpun dan menyalurkan dana masyarakat (anggota), semestinya mempunyai instrument keuangan yang sama dengan perbankan. Penghimpunan dana yang dilakukan BMT mengandung risiko yang sama dengan penghimpunan yang dilakukan perbankan. Penyaluran dana kepada nasabah (anggota) yang dilakukan BMT mempunyai risiko yang sama dengan yang dilakukan dunia perbankan. Akan tetapi regulasi, pengawasan dan instrument untuk mengendalikan kedua entitas lembaga keuangan ini jauh berbeda. Perbankan yang diawasi oleh OJK dengan regulasi yang ketat karena menyangkut kepercayaan public dalam menyimpan uangnya. Sementara BMT dengan persamaan penghimpunan dana tidak memiliki regulasi dan pengawasan yang memadai oleh regulatornya yaitu (Kementerian Koperasi dan UKM). Jadi BMT melakukan penghimpunan dana tanpa adanya lembaga penjamin simpanan, menyalurkan dana tanpa instrument pengendalian yang memadai. Akibatnya BMT menjadi lembaga keuangan yang membuat regulasi sendiri untuk dirinya sendiri (self regulation) dalam rangka menjaga risiko baik dari sisi penghimpunan dana maupun dari sisi penyaluran dana. Pengawasan dari Kementerian Koperasi dan UKM nyaris tidak ada, apalagi jangkuannya yang luas dengan jumlah Koperasi yang mencapai ratusan ribu di seluruh Indonesia, tidak memungkinkan untuk dilakukan pengawasan secara baik.

Manajemen risiko pada sebuah lembaga keuangan adalah hal yang harus diperhatikan dengan baik. Kesalahan mengelola risiko pada lembaga keuangan seperti BMT dan perbankan akan berakibat hilangnya kepercayaan masyarakat terhadap lembaga keungan. Krisis di tahun 1997/1998 adalah satu contoh dan pengalaman nyata akan ketidak percayaan masyarakat terhadap dunia perbankan yang berimbas pada krisi ekonomi yang multi dimensional.

Risiko likuiditas adalah risiko yang harus dijaga oleh lembaga keuangan, karena lembaga keuangan yang menghimpun dan menyalurkan dana akan berhadapan dengan persoalan likuiditas secara harian. Bila dana yang tersimpan di brankas terlau besar akan berisiko terhadap biaya dana (cost of capital) karena lembaga keuangan harus membayar bunga/bagi hasil kepada pemilik dana. Demikian juga bila lembaga keuangan kekurangan likuiditas, maka akan berakibat pada ketidak percayaan masyarakat pada lembaga keuangan tersebut dan bisa menyebabkan rush pada lembaga keungan bahkan bisa berimbas pada risiko sistematis atau sistemik.

Perbankan sebagai lembaga keuangan telah tersedia instrument dalam mengelola likuiditas, baik itu dari Bank Sentral (Bank Indonesia) yang menyediakan instrument bantuan likuiditas ataupun instrument surat berharga (commercial paper) antar bank yang telah dipercaya efektifitasnya. Namun BMT dengan fungsi penghimpunan dan penyaluran dana dari masyarakat (anggota) yang sama dengan perbankan, instrument semacam ini tidak dijumpai. Maka BMT secara bersama (berjamaah) harus melakukan inovasi untuk menghasilkan instrument yang bisa diterima bersama dan saling menguntungkan tidak ada satu pihak yang dirugikan.

Tawarruq adalah akan hybrid contract (al aqud al murakkabah) yang dapat dipergunakan oleh lembaga keuangan seperti BMT dalam memperoleh uang cash sebagai cadangan likuiditas untuk memenuhi kebutuhan likuiditasnya secara harian. Tawarruq yang ditawarkan untuk memenuhi kebutuhan likuiditas pada lembaga keuangan syariah seperti BMT ini adalah tawarruq munazzam (organized tawarruq) yang tidak menyimpang dari kaidah syariah dan diorganisir sebagaimana yang diatur dalam fatwa DSN MUI No. 82/DSNMUI/VIII/2011 tentang Bursa Komoditi.

Apa dan bagaimana tawarruq munazzam yang ditawarkan unutk menyelesaikan 
permasalahan likuiditas (manajemen likuiditas) pada lembaga keuangan syariah non bank (BMT) akan dibahas dalam artikel ini. Dengan demikian artikel ini dapat memberi kontribusi pemikiran sebagia salah satu solusi bagi lembaga keungan mikro syariah non bank (BMT) dalam mengelola likuiditasnya dan menjadi sumbangsih pengembangan ilmu pengetahuan khususnya bidang perbankan dan keuangan Syariah.

\section{METODOLOGI}

Penulisan artikel ini adalah bersifat deskriptif analitis dengan telaah pustaka yang berasal dari berbagai literature baik buku, jurnal, materi pelatihan dan internet sebagai data kualitatif yang merupakan sumber dari deskripsi yang luas dan berlandaskan kokoh, serta memuat penjelasan tentang prosesproses yang terjadi dalam lingkup setempat (Miles \& Huberman, 1992). Penulisan memilih menggunakan metode deskriptif analitis, untuk memahami secara mendalam akad tawarruq sebagai solusi manajemen likuiditas Lembaga Keuangan Mikro Syariah non bank (BMT).

Menurut (Bungin, 2007), Fokusnya ditekankan untuk mengungkap pokok soal yang hendak diteliti, sehingga di dalamnya terdapat penjelasan mengenai dimensidimensi apa yang menjadi pusat perhatian serta nantinya akan dibahas untuk mendapat pemahaman yang lebih dan hingga tuntas. Sedangkan (Sugiyono, 2009), menyatakan Fokus penelitian kualitatif diperoleh setelah dilakukan grand tour observation dan grand tour question atau yang disebut dengan penjelajahan umum.

\section{HASIL DAN PEMBAHASAN \\ Pengertian Tawarruq}

Kebutuhan likuiditas pada dunia perbankan merupakan hal yang tidak bisa dihindari. Lembaga keuangan syariah sebagai lembaga intermediary dari pemilik dana lebih untuk disalurkan pada pihak yang kekurangan dana, maka dibutuhkan pengelolaan likuiditas dengan baik agar kredibilitas dunia perbankan dapat dipertanggung jawabkan kepada pemilik dana baik investor maupun pihak ketiga sebagai pemilik dana yang disimpan di bank.

Fasilitas likuiditas pada perbankan konvensional telah lama berjalan dengan berbagai instrument baik antar bank maupun fasilitas likuiditas dari bank sentral. Tentunya semua instrument perbankan konvensional berbasis bunga yang dilarang dan harus dihindari oleh perbankkan syariah. Fasilitas likuiditas pada bank syariah saat ini masih menggunakan akad-akad berbasis ujroh seperti akad wadiah pada giro wadiah minimum, pasar uang antar bank syariah atau sertifikat mudharabah antar bank syariah. Akad-akad ini perlu dikaji efektifitasnya dan kesesuaiannya dengan syariah (sharia compliance), karena kebutuhan kas antar bank dengan akad-akad di atas tentu ada kelebihan dan kelemahannya. Misalnya akad mudharabah untuk kebutuhan likuiditas, maka harus jelas proyek atau objek yang dibagi-hasilkan, bila tidak ada objek khusus yang dibagi-hasilkan maka akad ini kurang tepat digunakan. Akad wadiah untuk keperluan pinjaman likuiditas juga kurang tepat karena tidak dapat memastikan return dari dana yang ditanam pada bank lain.

Tawarruq merupakan akad yang biasa digunakan untuk memperoleh dana cash secara cepat dengan cara menjual barang yang telah diperolehnya secara angsuran (kredit). Akad ini telah lama dipergunakan dan dapat ditemukan pada kitab-kitab fiqh klasik. Dalam aplikasinya pada perbankan modern tentunya harus dilakukan modifikasi sesuai perkembangan dan kebutuhan perbankan syariah saat ini.

Tawarruq pertama kali diperkenalkan pada tahun $1421 \mathrm{H}$ atau tahun 2000 Masehi di Saudi Arabia oleh Saudi British Bank dan Aljazira Bank pada tahun 2002, kemudian dipakai oleh perbankan di Negara-negara Timur Tengah sebagai produk dengan akah murabahah komoditas dan sebagai instrument manajemen likuiditas dan produk sukuk Negara atau sukuk corporate.

Secara bahasa tawarruq berasal dari kata warq - wariq - waraqa yang berarti perak 
(dirham). jika seseorang membeli barang dari seorang penjual dengan harga kredit lalu ia menjual barang tersebut secara kontan kepada pihak ketiga selain dari penjual. Dinamakan dengan nama At-Tawarruq juga dikatakan dari kalimat waraqoh yaitu lembaran uang, sebab pembeli yang merupakan pihak pertama sebenarnya tidak menginginkan barang tapi yang ia inginkan hanyalah mendapatkan uang sehingga ia bisa lebih leluasa menggunakannya. (umarazka.blogspot.co.id, 2012)

Jadi akad tawarruq dalam praktek perbankan syariah merupakan akad yang digunakan untuk memperoleh uang tunai atau cash dengan cara menjual asset (komoditas) yang diperolehnya secara hutang untuk memenuhi kebutuhan pendanaan jangka pendek. Akad ini juga bisa dipergunakan untuk nasabah yang memerlukan uang tunai dengan cara membeli asset dari pihak ketiga dengan cara berhutang atau pembiayaan yang didanai oleh bank syariah, kemudian nasabah menjual asset atau komoditas tersebut kepada pihak lain untuk mendapatkan uang tunai yang uang tunai tersebut didebet ke rekening nasabah pada bank syariah tempat transaksi pertama.

\section{Dasar Hukum Tawarruq}

DSN MUI telah mengeluarkan fatwa tentang perdagangan bursa komoditas yang diatur dalam (Fatwa DSN-MUI No: 82/DSN-MUI/VII/2011, 2011), Fatwa ini menjadi angin segar bagi perbankan syariah di Indonesia untuk mendesain produk dalam rangka memenuhi kebutuhan likuiditas perbankan syariah yang selama ini masih menggunakan akad wadiah atau akad lainnya.

Di dalam (Kementerian Agama RI: Al Qur'an dan Terjemahannya, 2013)(Al Qur'an), kata tawarruq atau wariq terdapat dalam Surat Al Kahfi (18) ayat 19 :

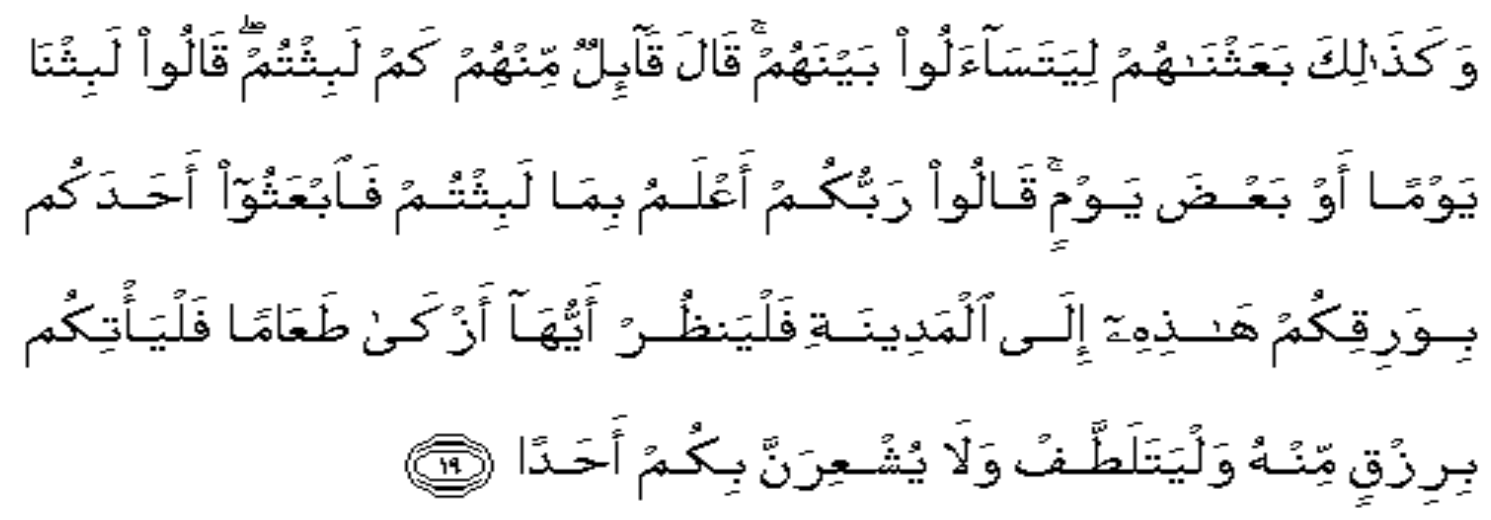

Artinya : "Dan Demikianlah kami bangunkan mereka agar mereka saling bertanya di antara mereka sendiri. berkatalah salah seorang di antara mereka: sudah berapa lamakah kamu berada (disini?)". mereka menjawab: "Kita berada (disini) sehari atau setengah hari". Berkata (yang lain lagi): "Tuhan kamu lebih mengetahui berapa lamanya kamu berada (di sini). Maka suruhlah salah seorang di antara kamu untuk pergi ke kota dengan membawa uang perakmu ini, dan hendaklah dia lihat manakah makanan yang lebih baik, Maka hendaklah ia membawa makanan itu untukmu, dan hendaklah ia berlaku lemah-lembut dan janganlah sekali-kali menceritakan halmu kepada seorangpun".

Akad tawarruq pada dasarnya bukan akad pembiayaan seperti pada umumnya. Akad ini hanya digunakan untuk memenuhi

kebutuhan likuiditas atau manajemen likuiditas perbankan syariah saja, karena lembaga perbankan berfungsi mengelola 
risiko. Bila kelebihan dana akan merugikan perbankan demikian pula bila kekurangan juga akan merugiakan perbankan syariah itu sendiri.

Dalam fatwanya, (Fatwa DSN-MUI No: 82/DSN-MUI/VII/2011，2011) mendasari pendapat para ulama klasik tentang tawarruq dan wakalah sebagai dasar operasional lembaga keuangan syariah melaksanakan bursa komoditas yang dapat dilaksanakan dengan akad tawarruq, diantaranya :

1. Pendapat Ibnu Qudamah:

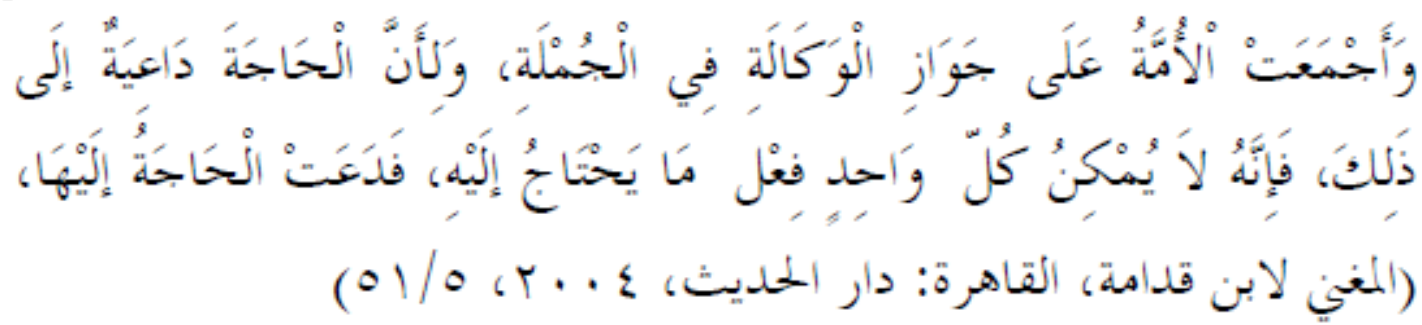

"Umat (ulama) telah sepakat bahwa secara garis besar wakalah itu hukumnya boleh; dan karena hajat (kebutuhan) orang pun mendorong untuk melakukan wakalah. Tidak setiap orang bisa melakukan langsung apa yang ia butuhkan. Dengan demikian, ada kebutuhan terhadap wakalah tersebut."

2. Pendapat Ibnu Qudamah :

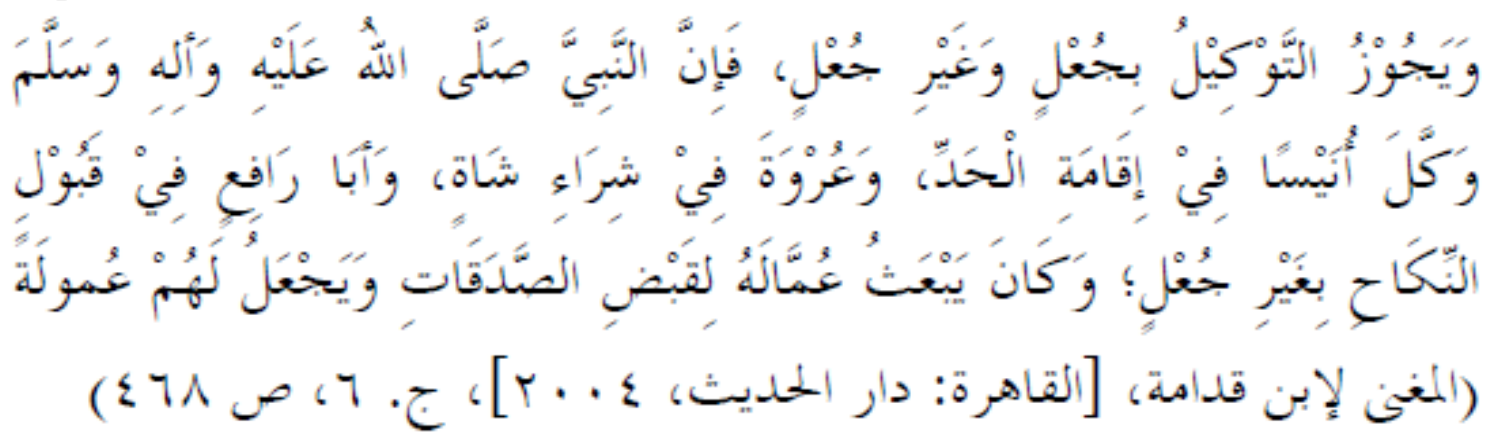

"Akad taukil (wakalah) boleh dilakukan, baik dengan imbalan maupun tanpa imbalan. Hal itu karena Nabi shallallahu 'alaihi wa alihi wa sallam pernah mewakilkan kepada Unais untuk melaksanakan hukuman, kepada Urwah untuk membeli kambing, dan kepada Abu Rafi' untuk melakukan qabul nikah, (semuanya) tanpa memberikan imbalan. Nabi pernah juga mengutus para pegawainya untuk memungut sedekah (zakat) dan beliau memberikan imbalan kepada mereka."

3. Pendapat Imam Syaukani:

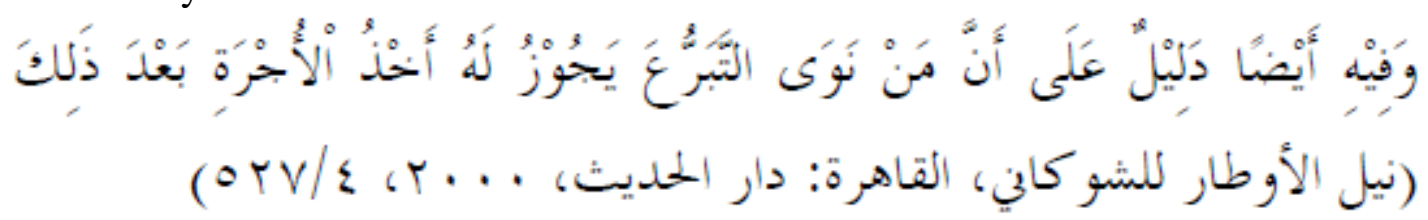

"Hadis Busr bin Sa'id tersebut menunjukkan pula bahwa orang yang melakukan sesuatu dengan niat tabarru' boleh menerima imbalan.”. 
4. Pendapat Tim Penyusun Ensiklopedi Fiqh Islam Kuwait :

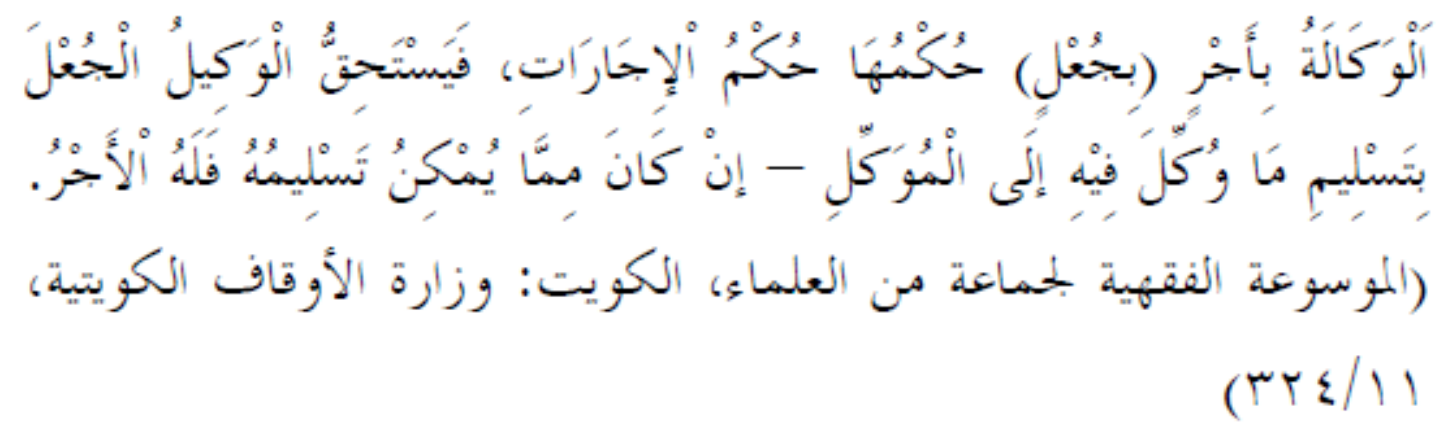

"Wakalah dengan upah (imabalan) hukumnya sama dengan hukum ijarah. Wakil berhak mendapatkan upah dengan menyerahkan obyek yang diwakilkan kepada yang mewakilkan jika obyek tersebut bisa diserah-terimakan, maka ia berhak mendapatkan upah”.

5. Pendapat al-Mirdawi :

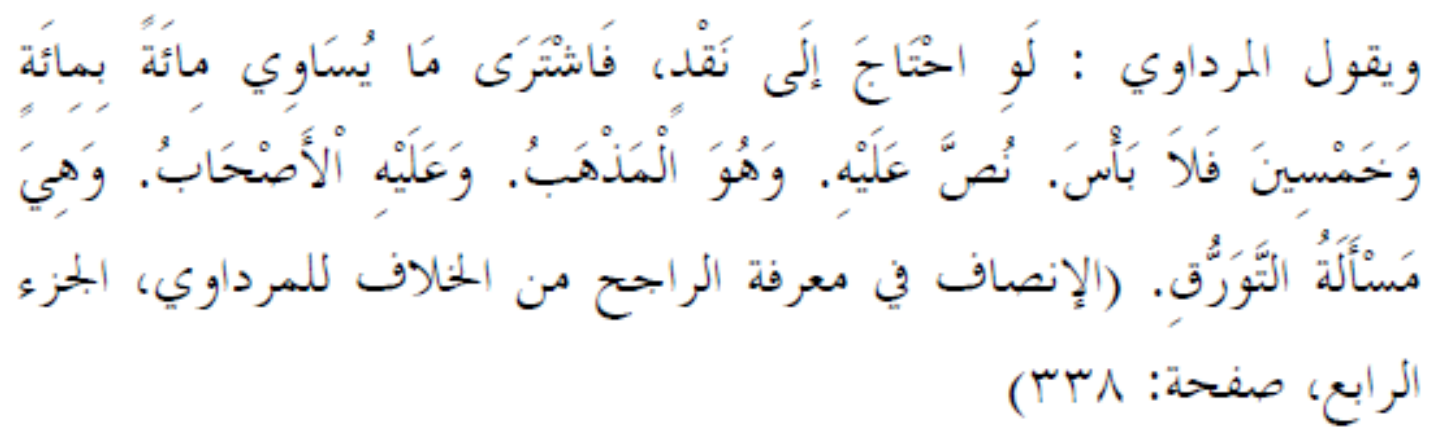

Imam al-Mirdawi berkata:" jika seseorang membutuhkan uang, kemudian ia membeli barang yang seharga 100 dengan harga 150, maka hukumnya boleh. Ini adalah pendapat Madzhab (Hanbali); dan masalah tersebut dinamakan tawarruq".

6. Pendapat Ibnu al Humam:

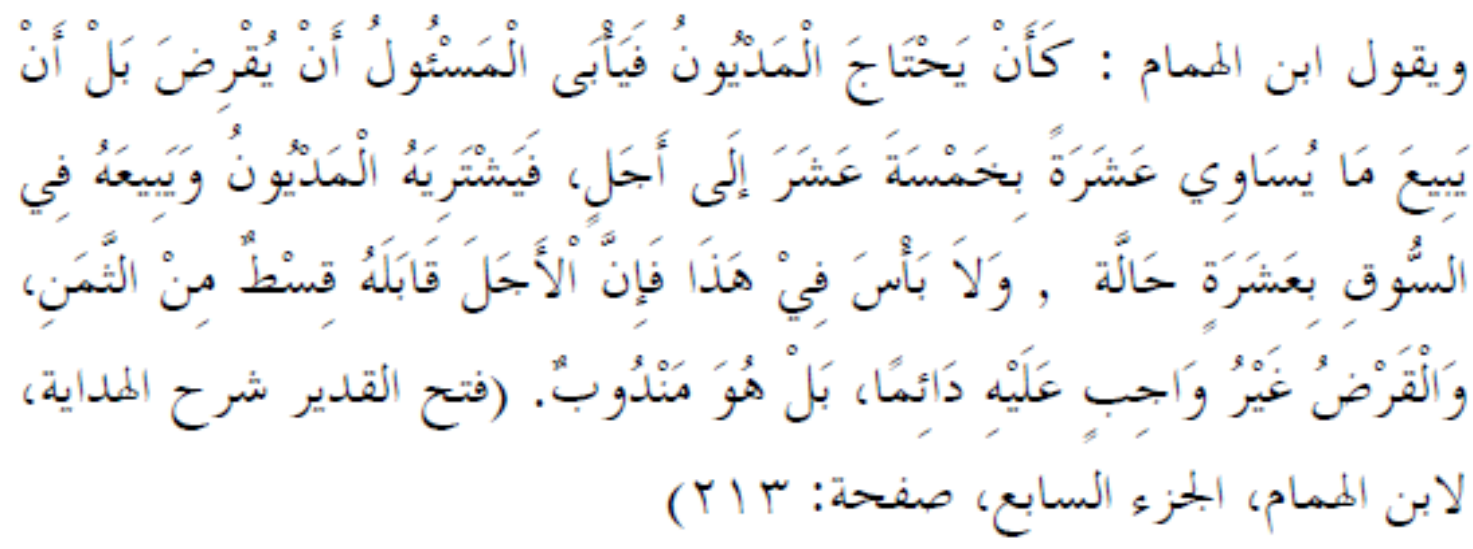

Ibnu al-Humam berkata: "Seperti orang mau berutang, tapi pihak yang diminta untuk memberikan utang enggan memberikan pinjaman (utang), ia malah menjual kepada orang itu barang yang seharga 10 dengan harga 15 secara tangguh. Kemudian orang itu pun membeli barang tersebut dan menjualnya di pasar dengan harga 10 secara tunai. Jual beli seperti itu 
hukumnya boleh, karena tangguh (kurun waktu pembayaran) itu berimbal harga. Sedangkan memberikan pinjaman (utang, qardh) hukumnya tidak wajib, tetapi sunnah".

7. Al-Ma'ayir Al-Syar'iyah. (2010, h. 413)

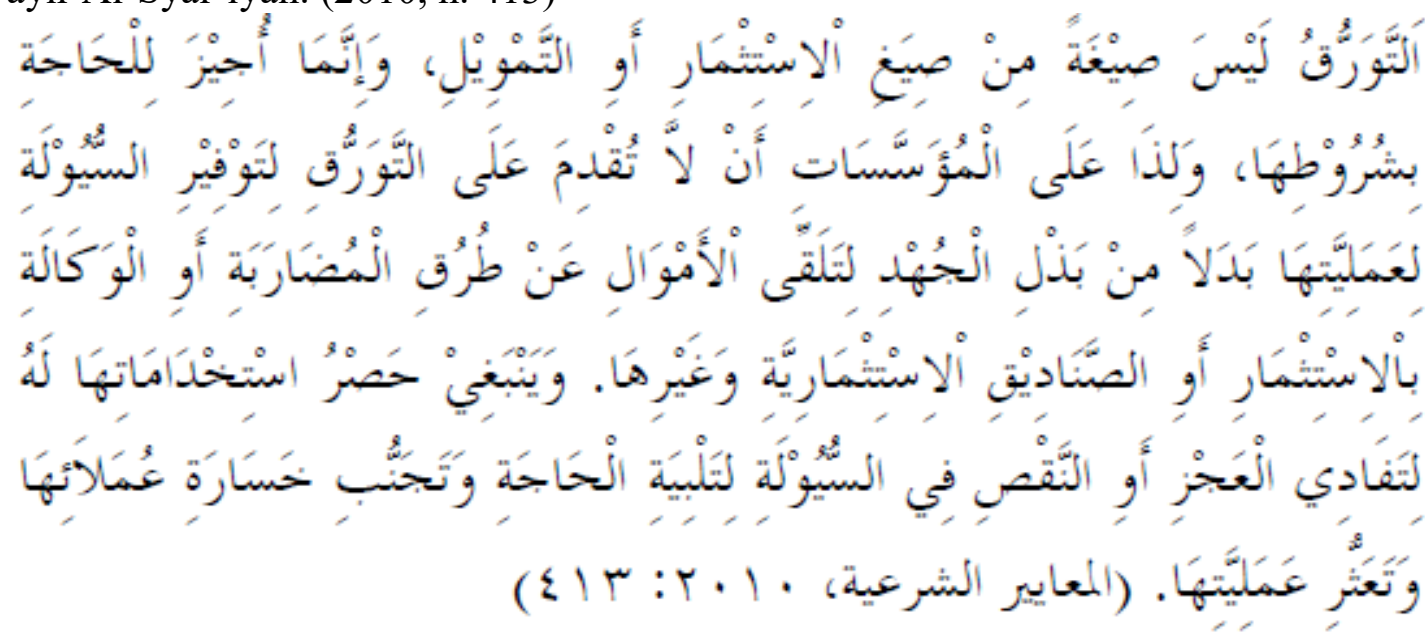

"Tawarruq bukan merupakan skema investasi maupun pembiayaan. Tawaruq hanya dibolehkan karena hajat (ada kebutuhan) dengan syarat-syarat yang harus dipenuhi. Oleh karena itu, lembaga keuangan syariah (LKS) tidak boleh melakukan tawaruq dalam memenuhi kebutuhan likuiditas operasionalnya, untuk menggantikan penerimaan dana melalui produk mudharabah, wakalah untuk investasi, produk reksadana, dan sebagainya. Tawaruq hanya boleh digunakan untuk menutupi kekurangan (kesulitan) likuiditas, menghindari (meminimalisir) kerugian nasabah, dan mengatasi kesulitan operasional LKS”.

(Fatwa DSN-MUI No: 82/DSNMUI/VII/2011, 2011) mengatur perdagangan komoditas agar tidak terjebak dalam riba, gharar dan maisir yang dilarang secara syar'ie, dengan ketentuan sebagai berikut :

\section{Ketentuan mengenai Perdagangan}

1) Komoditi yang diperdagangkan harus halal dan tidak dilarang oleh peraturan perundang-undangan;

2) Jenis, kualitas, dan kuantitas komoditi yang diperdagangkan harus jelas;

3) Komoditi yang diperdagangkan harus sudah ada (wujud) dan dapat diserahterimakan secara fisik;

4) Harga Komoditi yang diperdagangkan harus jelas dan disepakati pada saat akad (Ijab qabul);

\section{Ketentuan mengenai Bursa}

1) Bursa wajib membuat peraturan mengenai mekanisme perdagangan
5) Akad dilakukan melalui penawaran dan penerimaan yang disepakati para pihak yang melakukan perdagangan dengan cara-cara yang lazim berlaku di Bursa;

6) Penjual harus memiliki komoditi atau menjadi wakil pihak lain yang memiliki komoditi;

7) Penjual wajib menyerahkan komoditi yang dijual kepada pembeli dengan tata cara dan waktu sesuai kesepakatan;

8) Pembeli wajib membayar komoditi yang dibeli kepada penjual dengan tatacara dan waktu berdasarkan kesepakatan; dan

9) Pembeli boleh menjual komoditi tersebut kepada selain penjual sebelumnya/ pertama hanya setelah terjadi qabdh haqiqi atau qabdh hukmi atas komoditi yang dibeli.

komoditi yang tidak bertentangan dengan prinsipprinsip syariah;

2) Bursa wajib membuat peraturan mengenai mekanisme yang 
memungkinkan terjadinya serah fisik komoditi yang diperdagangkan;

3) Bursa tidak boleh membuat peraturan yang melarang terjadinya serah-terima fisik komoditi yang diperdagangkan; Bursa wajib menyediakan sistem perdagangan di Bursa;

4) Bursa wajib melakukan pengawasan terhadap perdagangan di Bursa;

5) Bursa boleh menetapkan syarat-syarat tentang pihak-pihak yang melakukan perdagangan di Bursa.

\section{Ketentuan mengenai Mekanisme Perdagangan Serah-Terima Fisik}

1) Konsumen Komoditi selaku pembeli memesan kepada Peserta Komersial dan berjanji (wa'd) akan melakukan pembelian komodiiti;

2) Peserta Komersial membeli komoditi dari sejumlah Peserta Pedagang Komoditi dengan pembayaran tunai (bai');

3) Peserta Komersial menerima dokumen kepemilikan yang berupa Surat Penguasaan Atas Komoditi Tersetujui (SPAKT) yang diterbitkan oleh Bursa melalui sistem, sebagai bukti atas pembelian komoditi dari Peserta Pedagang Komoditi;

4) Peserta Komersial menjual komoditi kepada Konsumen Komoditi dengan akad murabahah; dan diikuti dengan penyerahan dokumen kepemilikan;

5) Konsumen Komoditi membayar kepada Peserta Komersial secara tangguh atau angsuran sesuai kesepakatan dalam akad murabahah;

6) Konsumen Komoditi menerima fisik komoditi tersebut dari Peserta Komersial.

\section{Ketentuan mengenai Mekanisme Perdagangan dengan Penjualan Lanjutan}

2) Peserta Komersial membeli komoditi dari sejumlah Peserta Pedagang Komoditi dengan pembayaran tunai (bai');

3) Peserta Komersial menerima dokumen kepemilikan yang berupa Surat Penguasaan Atas Komoditi Tersetujui (SPAKT) yang diterbitkan oleh Bursa melalui sistem, sebagai bukti atas pembelian komoditi dari Peserta Pedagang Komoditi;

4) Peserta Komersial menjual komoditi kepada Konsumen Komoditi dengan akad murabahah; dan diikuti dengan penyerahan dokumen kepemilikan;

5) Konsumen Komoditi membayar kepada Peserta Komersial secara tangguh atau angsuran sesuai kesepakatan dalam akad murabahah;

6) Konsumen Komoditi mendapat jaminan untuk menerima komoditi dalam bentuk SPAKT dari Peserta Komersial; sehingga dengan demikian, telah terjadi qabdh hukmi;

7) Peserta Pedagang Komoditi mewakilkan kepada Bursa untuk membeli komoditi secara tunai dengan akad wakalah;

8) Konsumen Komoditi boleh menjual komoditi kepada Peserta Pedagang Komoditi secara tunai dengan akad bai' melalui Bursa selaku wakil pembeli (Peserta Pedagang Komoditi);

9) Konsumen Komoditi menyerahkan komoditi, dengan mengalihkan jaminan akan terjadinya serah fisik (SPKAT) yang diterima dari Peserta Komersial sebagaimana dimaksud dalam butir 6;

10) Konsumen Komoditi menerima pembayaran tunai dari Peserta Pedagang Komoditi;

11) Settlement (penyelesaian transaksi) Komoditi antar Peserta Pedagang Komoditi dilakukan dengan akad muqayadhah;

1) Konsumen Komoditi selaku pembeli memesan kepada peserta Komersial dan berjanji (wa'd) akan melakukan pembelian komoditi; 


\section{Ketentuan mengenai Agen dan Mekanisme Perdagangannya}

1) Penjual maupun pembeli komoditi di Bursa boleh menggunakan jasa agen dengan akad wakalah;

2) Agen penjual tidak boleh merangkap sebagai agen pembeli dalam transaksi yang sama / pada saat yang bersamaan;

3) Dalam hal agen penjual dalam kedudukannya sebagai wakil penjual merangkap sebagai pembeli dalam transaksi yang sama/pada saat yang bersamaan, kedudukan agen sebagai wakil gugur; selanjutnya agen berkedudukan sebagai pembeli;

4) Dalam hal kedudukan agen penjual sebagai wakil penjual, agen penjual tidak boleh menjanjikan keuntungan kepada penjual;

5) Dalam hal kedudukan agen penjual sebagai pembeli, agen patuh pada ketentuan perdagangan, dan terikat pada hak dan kewajiban pembeli;

6) Dalam hal agen pembeli dalam kedudukannya sebagai wakil pembeli merangkap sebagai penjual dalam transaksi yang sama/pada saat yang bersamaan, kedudukan agen sebagai wakil gugur; selanjutnya agen berkedudukan sebagai penjual;

7) Dalam hal kedudukan agen pembeli sebagai wakil pembeli, agen pembeli tidak boleh menjanjikan harga yang pasti kepada pembeli;
8) Dalam hal kedudukan agen pembeli sebagai pembeli, agen patuh pada ketentuan perdagangan, dan terikat pada hak dan kewajiban pembeli;

9) Ketentuan mengenai mekanisme perdagangan melalui agen merujuk pada ketentuan kelima dan keenam dalam fatwa ini.

\section{Produk-produk Tawarruq pada Perbankan dan Keuangan Syariah}

Akad tawarruq telah dipakai di perbankan syariah di Malaysia dan di Perbankan Syariah negara-negara timur tengah. Perbankan Syariah Malaysia memakai akad tawarruq tidak terbatas pada bank sebagai liquidity seeker, tetapi dipakai juga untuk akad pembiayaan perseorangan. Aplikasi tawarruq untuk nasabah bank syariah ini mendapat banyak kritik dari para ahli fiqh karena menyerupai bai' al inah dengan kecendurungan pada hilah kepada riba.

Di Indonesia akad tawarruq dipergunakan untuk transaksi pada bursa komoditi seperti yang difatwakan oleh (Fatwa DSN-MUI No: 82/DSN-MUI/VII/2011，2011). Aplikasi perbankan syariah oleh bank syariah kepada nasabah sampai saat ini belum dilakukan oleh perbankan syariah di Indonesia. (ISRA, 2013) menjelaskan aplikasi tawarruq pada lembaga keuangan dan keuangan Islam seperti pada gambar berikut : 
Gambar 0.1 : Aplikasi Tawarruq pada Lembaga Keuangan Syariah

\begin{tabular}{|l|l|}
\hline Deposit & $\begin{array}{l}\text { Commodity murabahah deposit facility } \\
\text { and placement }\end{array}$ \\
\hline Financing & $\begin{array}{l}\text { Personal financing, asset financing, } \\
\text { cash line facility, contract financing, } \\
\text { commodity murabahah financing, } \\
\text { education financing, revolving credit } \\
\text { facility, working capital financing, home } \\
\text { financing, project financing facilities }\end{array}$ \\
\hline $\begin{array}{l}\text { Liquidity } \\
\text { Management } \\
\text { and Debt }\end{array}$ & $\begin{array}{l}\text { BNM Islamic accepted bills (IABs), } \\
\text { islamic private debt securities (IPDSs), } \\
\text { interbank commodity murabahah. }\end{array}$ \\
\hline $\begin{array}{l}\text { Government and } \\
\text { Corporate Sukuk } \\
\text { Financing }\end{array}$ & $\begin{array}{l}\text { Sukuk ijarah, sukuk murabahah } \\
\text { Risk } \\
\text { Managemen } \\
\text { and Hedging Pur- } \\
\text { poses }\end{array}$ \\
\hline
\end{tabular}

Gambar di atas terlihat bahwa tawarruq dapat digunakan untuk berbagai macam skim baik sisi sumber pendanaan maupun sisi penggunaan dana. Dari sisi sumber dana tawarruq dapat diturunkan untuk produk komoditi murabahah dan penempatan deposito. Pada sisi pembiayaan, tawarruq dapat digunakan pada skim pembiayaan personal, pembiayaan asset, cash line facility, pembiayaan komoditi murabahah, pembiayaan untuk pendidikan, revolving credit, pembiayaan modal kerja, pembiayaan perumahan, pembiayaan proyek dan skim lainnya dengan pola tawarruq.

Tawarruq juga bisa digunakan dalam manajemen likuiditas perbankan dan lembaga keuangan syariah dan restrukturisasi pembiayaan/kredit dengan berbagai bentuk skim produk misalnya L/C dengan pola syariah, sekuritas hutang swasta dan fasilitas likuiditas antar bank. Sektor pemerintahan dan korporasi dapat menerbitkan sukuk ijarah dan murabahah berbasis akad tawarruq. Tawarruq dapat pula dipakai sebagai sarana lindung nilai (hedging) perdagangan untuk memproteksi risiko dengan pola swaps ijarah, lindung nilai valuta dan lindung nilai fluktuasi suku bunga yang tidak menentu.

\section{Bentuk-bentuk Tawarruq}

Di Indonesia beberapa lileratur membagi jenis tawarruq menjadi dua yaitu tawarruq fiqhi dan tawarruq munazzam. Tawarruq munazzam tidak dikenal dalam kitab fiqh klasik karena tawarruq dalam konteks asalnya adalah tawarruq individu yang tidak melibatkan lembaga seperti yang terjadi saat ini. Perkembangan institusional keuangan syariah saat ini menuntut desain baru akad tawarruq agar dapat diaplikasikan dalam lembaga keuangan dan perbankan syariah.

International Shari'ah Reseach Academy for Islamic Finance (ISRA, 2013) membagi tawarruq menjadi :

1) Al-Tawarruq al-Fardi atau Tawarruq berbasis Individu atau Classical Tawarruq.

The OIC Fiqh Academy mendefinisikan tawarruq jenis ini sebagai pembelian komoditi secara non tunai kemudian menjualnya kembalai secara tunai kepada pihak 
lain untuk mendapatkan dana cash (al-wariq)

2) Al-Tawarruq (Organized Tawarruq):

OKI Fiqh Academy mendefinisikan tawarruq munazzam "ketika seseorang (mustawariq / mustawriq) membeli komoditi dari pasar lokal maupun internasional secara tangguh (differed). Lembaga keuangan mengatur perjanjian jual baik kepada lembaga keuangan itu sendiri atau melalui agen. Kemudian mutawarriq dan lembaga keuangan melakukan transaksi,dengan harga spot yang lebih rendah. "

3) Al-Tawarruq Al-Masrafi (Banking Tawarruq):

Tawarruq Perbankan, adalah bentuk lain dari Tawarruq terorganisir (tawarruq munazzam) adalah proses di mana lembaga keuangan syariah resmi mengatur penjualan komoditas (selain emas atau perak) antara pasar komoditas internasional atau lokal dan mutawarriq, dengan pembayaran tunda (differed) yang diikat oleh akad atas komoditas tersebut. Lembaga keuangan syariah, akan mewakili mutawarriq dalam menjualnya ke pembeli lain untuk mendapatkan uang tunai, kemudian bank akan membayar kepada mutawarriq (Bouheraoua, 2009).

4) Reverse Tawarruq:

Sebagaimana Tawarruq Munazzam, bedanya, Mutawarriq-nya adalah lembaga keuangan atau perbankan syariah sebagai pencari likuiditas.

\section{Efek Negatif dari Akad Tawarruq}

Akad tawarruq tetap menjadi perdebatan di kalangan ahli ekonomi dan keuangan syariah terutama akad tawarruq munazzam yang tidak dikenal dalam tawarruq klasik (tawarruq fardhi). M. Nejatullah Sidqi seperti dikutip (Samsuri, 2015), menyatakan bahwa konsep tawarruq ini lebih besar mafsadahnya daripada maslahahnya, jika dilihat dari segi kepentingan umum. Di bawah ini adalah mafsadah yang telah dirangkum oleh Sidqi:

1) Tawarruq menyebabkan pembentukan utang yang mana volumenya cenderung mengalami peningkatan.

2) Hasil pertukaran (exchange) uang sekarang dengan uang dikemudian hari adalah tidak fair dari segi sudut pandang resiko dan termasuk ketidakpastian.

3) Hal ini menyebabkan perkembangbiakan utang secara terus menerus, menuju arah perjudian seperti transaksi spekulasi

4) Hal ini menyebabkan keuangan berdasarkan utang (debt fi nance) yang terus menerus, meningkatkan ketidak stabilan dalam ekonomi. Dalam debtbased economy, suplay uang dihubungkan kepada utang yang mana tendency kedepannya adalah peningkatan (expantion) lonjakan infl asi.

5) Ini menghasilkan ketidakadilan dalam distribusi pendapatan dan kesejahteraan. Dan menghasilkan keuangan berdasarkan utang yang terus menerus, dalam ketidakefesienan alokasi sumber daya.

6) Dengan pengkonsolidasian pembiayaan berbasis utang (debt fi nancing) berkontribusi untuk meningkatkan tingkatan (level) kekha watiran dan kerusakan (destruction) lingkungan

\section{Mekanisme Tawarruq untuk Manajemen Likuiditas Lembaga Keuangan Mikro Syariah non Bank (BMT)}

BMT sebagai lembaga keuangan mikro syariah keberadaannya telah diakui membantu masyarakat terutama masyarakat kelas bawah dalam mengembangkan usahanya. Lembaga ini berbadan hukum Koperasi yang pada mulanya para aktivis enggan untuk berbadan hukum Koperasi, namun karena tidak ada bentuk badan hukum lain yang sesuai selain Koperasi, maka BMT di seluruh Indonesia saat ini berbadan hukum Koperasi. Karena bila dipaksakan berbadan hukum Perbankan, maka akan kesulutan dalam memenuhi regulasi dari OJK atau BI. 
Bila berbadan hukum Lembaga Keuangan Mikro terbentur pada aturan terbatasnya wilayah operasional, harus melibatkan Pemda sebagai pemodal, harus menjadi BPR/BPRS bila sudah mencapai asset tertentu. Maka badan hukum Koperasi adalah yang paling sesuai dengan karakteristiknya dalam menghimpun dana (dana anggota) dan menyalurkan dana (kepada anggota).

Sebagai entitas berbadan hukum Koperasi yang melaksanakan praktek sebagaimana perbankan, maka BMT sering mengalami kesulitan likuiditas, karena dana yang dihimpun harus disalurkan untuk pembiayaan dengan jangka waktu rata-rata 12 bulan, sementara tabungan yang dihimpun dapat diambil setiap saat. Maka hal ini memaksa BMT harus menyediakan likuiditas yang cukup setiap harinya. Keadaan seperti ini sering menimbulkan masalah. Di beberapa daerah bahkan masalah satu BMT berimbas secara sistematis kepada BMTBMT lain di daerah tersebut (bisa satu Kabupaten). Bila hal ini tidak ada pemikirian sebagai solusi dalam jangka panjang, maka masalah kekurangan likuiditas pada BMT akan berulang.

(Fatwa DSN-MUI No: 82/DSNMUI/VII/2011, 2011) sesungguhnya memberikan solusi atas masalah manajemen likuiditas lembaga keuangan mikro seperti BMT, namun implementasi dari fatwa tersebut perlu disesuaikan dengan kondisi BMT dimana tidak memungkinkan untuk beroperasi di pasar komoditi yang letaknya di Jakarta. BMT dapat memanfaatkan jaringan induknya seperti Puskopsyah (Pusat Koperasi Syariah) yang sudah terbentuk di setiap daerah untuk dioptimalkan. Untuk broker pasar komoditi Puskopsyah BMT dapat membentuk Strategic Business Unit (SBU) dan bekerja sama dengan Bank Syariah dalam penyediaan dana. Komoditi seperti emas dan perak dapat diperolehnya dengan melibatkan pemilik modal, perbankan atau BMT lain yang kelebihan likuiditas untuk terlibat dan saling membantu (ta'awun atau takaful) BMT yang kekurangan likuiditas, sehingga manajemen likuiditas BMT dapat terjaga dengan baik dan kepercayaan masyarakat akan meningkat untuk menginvestasikan dananya di semua BMT di seluruh Indonesia.

Untuk lebih jelasnya mekanisme akad tawarruq sebagai solusi manajemen likuiditas BMT dapat dilihat pada bagan berikut : 
Bagan 1 : Mekanisme Tawarruq pada LKMS non Bank (BMT)

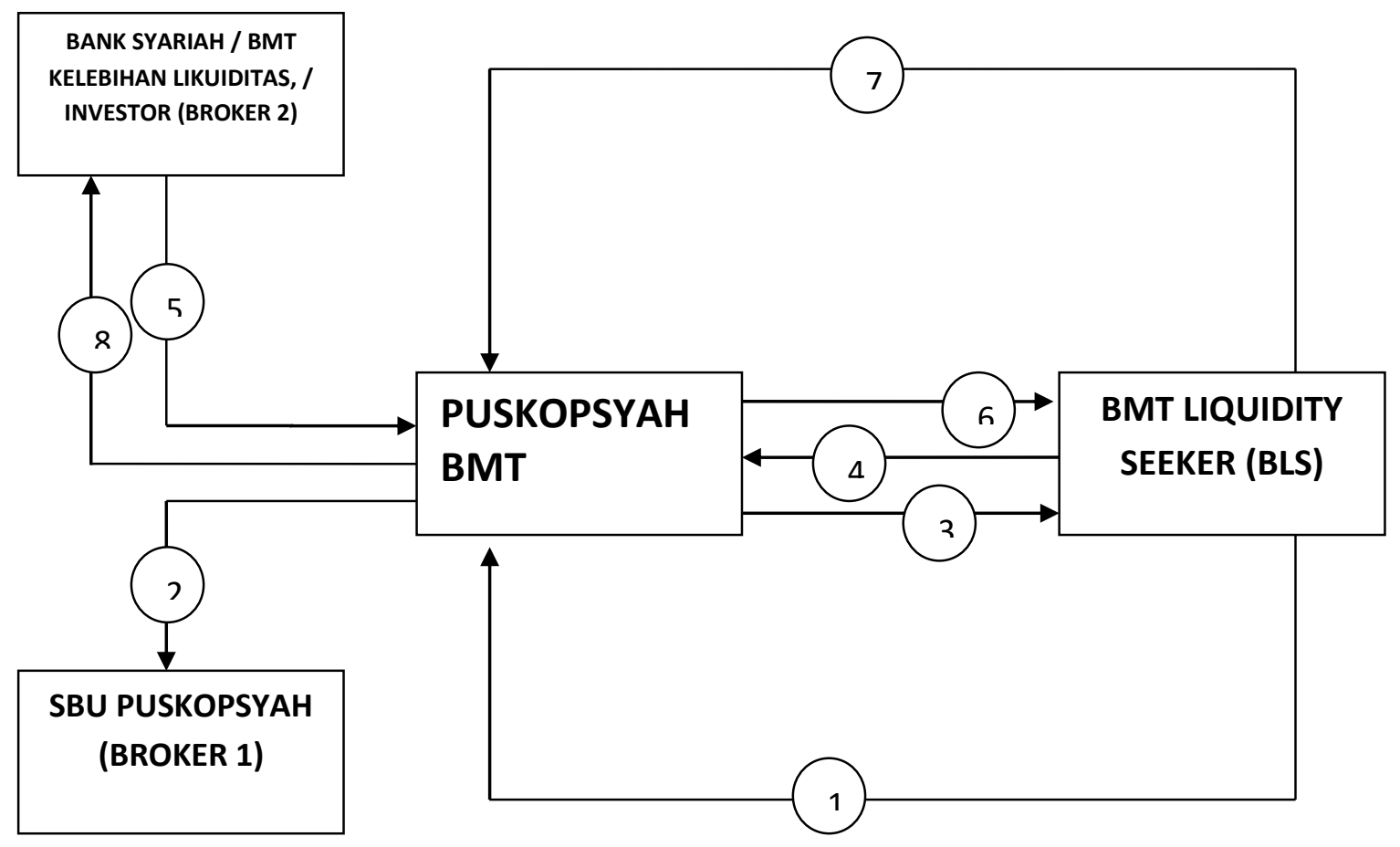

Proses dan langkah aplikasi tawarruq pada lembaga keuangan syariah (tawarruq munazzam) :

1) BMT Liquidity Seeker (BLS) mengajukan aplikasi tawarruq kepada Pusat Koperasi Syariah (Puskopsyah).

2) Puskopsyah membeli komoditi melalui broker 1 (Strategic Business Unit (SBU) Puskopsyah)

3) Puskopsyah menjual komoditi kepada BLS dengan akad murabahah (pokok+margin) dengan pembayaran non tunai (cicilan atau tangguh).

4) Dengan akad wakalah BLS meminta Puskopsyah BMT untuk menjual komoditi ke pasar komiditi (pihak lain yang memiliki dana)/Broker 2/Bank Syariah.

5) Bertindak sebagai wakil dari BLS sesuai poin no 4, Puskopsyah menjual komoditi kepada broker 2 .

6) Broker 2 kemudian memasukkan dana hasil penjualan komoditi ke rekening BLS (BLS mendapatkan dana tunai).

7) BLS membayar pelunasan kepada Puskopsyah (pokok + margin) sesuai akad yang telah desepakati pada akad di awal.

8) Puskopsyah melunasi (pokok dan bagi hasil/margin) kepada Broker 2

Yang perlu digaris bawahi pada mekanisme di atas adalah bahwa ini adalah tawarruq munazzam yang melibatkan pihak yang memiliki dana. Pemilik dana tersebut bisa Bank Syariah atau BMT besar yang kelebihan likuiditas atau investor individu yang memiliki kelebihan dana kemudian diorganisir oleh Puskopsyah BMT sebagai Manajer Investasi.

Keuntungan dari mekanisme ini dapat dibagi kepada pemilik dana, SBU Puskopsyah dan Puskopsyah sendiri. Untuk menghindari riba dan praktek gharar dan maisir, maka komoditi yang diperdagangkan harus benar-benar riil dan wujud sebagai underlying. Bila komoditi yang diperdagangkan bersifat fiktif, maka mekanisme ini batal secara fiqh.

Kunci keberhasilan dari mekanisme ini adalah dari perkumpulan BMT itu sendiri yang membentuk Puskopsyah dan membentuk SBU serta mencari mitra pemilik dana bisa Bank Syariah, BMT yang 
kelebihan dana atau investor lain untuk terlibat dalam mekanisme ini dengan pola bagi hasil yang saling menguntungkan.

Ada beberapa syarat agar mekanisme ini dapat diaplikasikan dengan baik dan berhasil

1) Pengukuran kebutuhan likuiditas BMT secara tepat.

Mengukur kebutuhan likuiditas BMT tidak persoalan sederhana. Kecermatan mengukur kebutuhan likuiditas berdasarkan teori dan manajemen likuiditas harus dilakukan oleh seorang manajer dalam hal ini pengurus dan pengelola Puskopsyah sebagai penyelenggara utama mekanisme ini. Kesalahan pengukuran likuiditas dapat berakibat fatal, maka kemampuan bayar BMT anggota harus decermati dan dianalisis dengan seksama. Jangan sampai pengukurannya melebihi batas kemampuan BMT yang akan mengakibatkan gagal bayar di kemudian hari atau di bawah kebutuhannya yang mengakibatkan BMT gagal menyediakan kebutuhan likuiditas untuk pengambilan tabungan yang dilakukan oleh mitra atau anggotanya.

2) Kebersamaan BMT dalam mendukung mekanisme

Selama ini BMT-BMT berjalan sendirisendiri tanpa terorganisir dengan baik oleh asosiasi atau organisasi yang menaunginya. Padalah BMT sebagai institusi keuangan sangat membutuhkan lembaga semacam APEX BMT. Pembentukan lembaga ini diperlukan regulasi yang rumit dan melibatkan ligislatif, eksekutif dan yudikatif secara integral. Bila BMT-BMT menunggu terwujudnya regulasi dan kelembagaan APEX BMT, maka sepuluh atau bahkan seratus tahun lagi belum tentu terbentuk. Maka BMT-BMT secara berjamaah dalam rangka mengorganisir kepentingan bersama perlu mengoptimalkan Puskopyah yang telah dibentuk dan diorganisir dalam rangka mewujudkan manajemen likuiditas yang baik agar ketersediaan dana likuiditas setiap saat dapat dipertanggung jawabkan kepada pemilik dana (mitra/anggota).

3) Simbiosis mutualisme Puskopsyah BMT - Pemilik Dana - SBU Puskopsyah BMT Bank Syariah sesungguhnya dapat masuk pada mekanisme ini sebagai pemilik dana (shohibul maal) dan ikut serta menyukseskan mekanisme ini dengan SDM dan teknologi yang dimilikinya, Bank Syariah sangat memungkinkan mengambil andil besar dalam mekanisme ini. Keterlibatan Bank Syariah tidak terlepas dari kepentingan bisnis, karena Bank Syariah harus menikmati keuntungan dari mekanisme ini. Sesungguhnya mekanisme ini sangat menguntungkan bagi semua pihak. Bagi BMT diuntungkan dengan ketersediaan likuiditas setiap waktu walaupun harus menanggung biaya sebagai konsekuensi logis dari mekanisme bisnis. Puskopsyah dan SBUnya diuntungkan dengan bagi hasil yang dihimpunnya dari BMT pencari likuiditas, keuntungan inilah yang harus dibagi kepada Bank Syariah selaku pemilik dana dan kepada BMT-BMT anggotanya melalui mekanisme SHU yang dibagikan setiap tahun.

4) Komoditi yang diperdagangkan adalah komoditi bernilai yaitu emas dan perak

Emas adalah komoditi yang sangat mungkin dijalankan saat ini. Emas yang dipergunakan sebagai komoditi bisa berbentuk emas batangan. Harga emas yang stabil dan cenderung naik menjadi komoditas menarik untuk dilaksanakannya mekanisme ini. Kenaikan harga emas dapat membantu meringankan biaya BMT pencari likuiditas.

5) Puskopsyah BMT sebagai manajer investasi menjalankannya secara profesional

Mekanisme ini harus dipersiapkan dengan baik melalui pelatihan intensif kepada karyawan atau pengurus Puskopsyah, Manajer dan Karyawan SBU Puskopsyah dan sosilalisai intens kepada BMT-BMT anggota Puskopsyah agar mekanisme dapat dijalankan dengan baik. 
Pemahaman fikih muamalah juga harus dilakukan agar tidak terjebak kepada transaksi grarar, maisir dan riba atau transaksi yang hilah kepada riba.

\section{KESIMPULAN}

1. Akad Tawarruq sebagai produk pemikiran masa lalu para ulama dapat dirivitalisasi berdasarkan kebutuhan masa kini untuk memenuhi kebutuhan likuiditas lembaga keuangan mikro syariah non bank (BMT) yang dalam prakteknya belum mempunyai instrumen yang tepat dalam memperoleh dana likuiditas seperti halnya perbankan syariah.

2. Dalam mengorganisir tawarruq sebagai sebuah produk untuk memenuhi kebutuhan likuiditas BMT oleh Puskopsyah BMT yang telah dibentuk dan dimiliki oleh BMT-BMT dalam satu wilayah, melibatkan pertama SBU (Strategik Business Unit) Puskopsyah dan pemilik dana (bisa investor pribadi, bank syariah atau BMT lain yang kelebihan likuiditas) untuk bekerjasama sinergi dan saling menguntungkan (simbiosis mutualisme).

\section{DAFTAR PUSTAKA}

Bungin, B. (2007). Analisis Data Penelitian

Kualitatif. . Jakarta: : PT.Raja

Grafindo.
Fatwa DSN-MUI No: 82/DSN-MUI/VII/2011.

(2011). PERDAGANGAN KOMODITI BERDASARKAN PRINSIP SYARIAH DI BURSA KOMODITI. Jakarta Pusat 10320: DSN MUI.

ISRA. (2013, September ). Fatwa in Islamic

Finance. (I. M. Tijani, Penyunt.) $A$

SNAPSHOT OF TAWARRUQ IN

CONTEMPORARY ISLAMIC

FINANCE , hal. 1 -5 .

Kementerian Agama RI: Al Qur'an dan

Terjemahannya. (2013). Al Qur'an dan

Terjemahannya. Jakarta Selatan: PT.

HATI EMAS.

Miles, M., \& Huberman. (1992). Analisis Data

Kualitatif. Jakarta: UI Press. Jakarta:

UI Press.

Samsuri, A. (2015, Januari). Membincang Konsep Tawarruq dalam Dunia Perbankan Dewasa ini. UNIVERSUM, Vol. 9 No. 1 hal 29 - 36.

Sugiyono. (2009). Metode Penelitian Bisnis (Pendekatan kualitatif, kuantitatif dan $R \& D)$. Bandung: Alfabeta.

umarazka.blogspot.co.id. (2012). http://umarazka.blogspot.co.id/2012/12 lapa-itu-akad-tawarruq.html diakses 06/04/2016 pukul 15:46. Diambil kembali dari http://umarazka.blogspot.co.id/2012/12 /apa-itu-akad-tawarruq.html diakses 06/04/2016 pukul 15:46 